\title{
Performance Evaluation of Single Slope SOLAR STILL BY INTEGRATING WITH SOLAR THERMAL SYSTEMS
}

\section{R. Sivakumaran*, P. Jdihesh}

Department of Mechanical Engineering, Sri Ramakrishna Engineering College, Coimbatore, Tamil Nadu, INDIA

*Email for Correspondence: sivaaero39@gmail.com.com

Manuscript Received: 22 September $2019 \quad$ - $\quad$ Revised: 13 December 2019 - Accepted: 27 January 2020

Abstract

The world is facing the state of being scarce of fresh or drinking water and it is the major problem and global challenge. Along with air and food, water is a basic necessity for human. Solar energy is the biggest source of energy available on earth. A solar distillation is one of the methods for purifying salt water to drinking water. In this method fresh water is obtained by exposing a small layer of salt water to solar radiation and the water vaporized from the basin is condensed on the bottom side of a taper transparent cover. It can be collected in receiving troughs at the end of the still. For this research, a solar still has been designed, fabricated and tested under the climate condition of Coimbatore (11.01680 N, 76.9550 E), India from December 2016 to March 2017. The still basin area was $1 \mathrm{~m} 2$ and the glass cover of still is inclined at 13 degree based on the city latitude. Solar still is integrated with thermal system such as solar photovoltaic system and then with solar pond in order to preheat the feed water thereby increasing the productivity considerably. Experiments were carried out on the still using different parameters and tested for performance. The results showed that the daily production of the conventional solar still was $2 \mathrm{Lit} / \mathrm{m} 2 /$ day and integrated with photovoltaic system and solar pond was $3.1 \mathrm{Lit} / \mathrm{m} 2 /$ day and $2.54 \mathrm{Lit} / \mathrm{m} 2 /$ day respectively.

Key words

Single Slope Solar, Performance Evaluation, Solar Thermal Systems

This article is is licensed under a Creative Commons Attribution-NonCommercial 4.0 International License.

Attribution-Non Commercial (CC BY-NC) license lets others remix, tweak, and build upon work non-commercially, and although the new works must also

acknowledge \& be non-commercial.

\section{INTRODUCTION}

Naturally, solar desalination produce rain when solar radiation is absorbed by the sea and cause water to evaporate (Al-Kharabsheh SS et al., 2004). In 1872, a first known application of solar distillation is used for providing drinking water to animals and also used in nitrate milling in Las Salinas, northern deserts of Chile. A solar still works on the principle of hydrological cycle found in the nature. Recently several types of solar stills have been built in Australia, Greece, Spain and some other countries. The new technologies as well as practical development is improving the productivity of solar stills. Surveys show that about 79 percent of water available on the earth is salty, only one percent is fresh and the remaining 20 percent is brackish water (Kaushal et al., 2010; Kianifar et al., 2012; Sampathkumar et al., 2010).Without fresh water (less than 500 parts per million of salts) human life is impossible. Water is a key to human prosperity associated with evolution of civilization.

Supply of drinking water is a major problem in underdeveloped and some of the developed countries. This problem occurs in recent years due to population growth, climate change, drought, urbanization (Sharon et al., 2015) etc. Safe water is more essential for healthy life and sustainable development. Nowadays, safe water is inadequate mostly in south Asia and Africa. Today, most of the diseases are due to the deficiency of clean drinking water. Most part of the lands in the world receive insufficient rainfall resulting in increased water salinity. All around the world, 3.575 million people die every year because of water related diseases (A.E. Kabeel et al., 2016). Although water occupy approximately $70 \%$ of the earth, more than $90 \%$ of the water contain salt and is not suitable for drinking (A.Muthu Manokar et al., 2014). Most of the water available is naturally impure or not drinkable and requires treatment (A.AEl-Sebaii et al., 2015). By the year 2025, it is estimated that $1 / 4$ of the world population will be affected by water scarcity and $2 / 3$ will experience water stressed conditions. By 2030,1/2 of the world population will face high water stress (fewresources.org 
2016). Presently, $31 \%$ of the population of African regions, $25 \%$, of Asia, $7 \%$ of America and $2 \%$ of Europe are experiencing high water stress (Kabeel AE et al., 2011; Bakkes JA et al., 2008; Arnell NW; Barker R et al., 1999).

Many U.N organizations like UNDP, WHO and World Bank are recently involved in implementing projects concerning the supply of pure water for drinking purpose. Many parts of the world contain plenty of underground water but this is highly saline (2000 ppm to $3500 \mathrm{ppm}$ ) and this water is unfit for drinking. The sea water contains $35000 \mathrm{ppm}$ impurities, out of this $28000 \mathrm{ppm}$ is common salt which is sodium chloride and it is essential for our body. The highest level of acceptance of salt content in the drinking water for human is only $500 \mathrm{ppm}$. For agriculture, the salt content is about 1000 ppm and many crops can grow even in high salt content (Garg H P et al., 2009). For industrial purpose, the level of acceptance of salt varies to great extent. For example in steam power generation, very pure water with a dissolved salt of only $10 \mathrm{ppm}$ is used. In many countries water standards are followed for drinking, agriculture and industries.

Desalination is one of the humankind's primitive forms of water handling, and it is the most popular treatment throughout the earth today (Hitesh $\mathrm{N}$ et al., 2016). In addition, distillation technique is used in land-based plants as well as in ships to provide water for a crew. Methods to convert saline water into potable water is of many types. They are desalination, vapour Compression, Reverse Osmosis, and Electro dialysis. These methods are energy intensive techniques and are not feasible for large fresh water demand. These desalination technologies were described in many researches. Solar still is one of the prominent, cheapest and environmental friendly methods. The components include glass cover, basin, absorber plate, insulation, distillate trough etc. solar still is a device used for the potable water production from salt water. It has lower distillate output; hence, it is required to be improved by any manner. Solar stills are mainly graded accordingly to passive and active systems based on the source of heat to evaporate the salt water directly through the sunrays or coupling some external sources like solar heater, $\mathrm{PV} / \mathrm{T}$ systems, waste heat source, solar ponds and concentrators to the stills. In addition, the active and passive system is subdivided into single and multi-effect stills based on number of layer of glazing.

To control and reduce the water crisis all over the world, a method of desalination of salt water can be preferred with low cost by using solar energy to produce a fresh water. But the limitation leads to low productivity. So solar still has to be integrated with solar thermal storage systems to enhance the yield to the better extend. As a research a photovoltaic system and solar pond can be used as an integrating components. Thus by integrating with these systems the yield of the solar still increase gradually and results are discussed given below.

\section{Materials AND Methods}

\section{Solar Still}

The solar still is divided into two types, active and passive still and their sub divisions are indicated in the flowchart figure 2. Solar still is an airtight basin, constructed using insulated materials, with top cover made of transparent materials like glass or plastic. The inner surface of the rectangular base was blackened to efficiently absorb the solar radiation incident on the surface. During operation, solar radiation is transmitted through the top glass cover and absorbed by the salt water in the inner basin. The water gets evaporated and the vapor rises to the top cover by convection where it is condensed on the bottom side of the cover. The condensate flow into the lower edges of the cover due to gravity. Due to surface tension the water flow into troughs without dropping back into the basin.

\section{Solar Still Design}

Conventional single slope solar still is the simplest type of still, which is easy to fabricate. In this research work a single slope solar still is fabricated and the performance analysis of the still was found. The operation of conventional solar still is shown in figure 1. The components of the solar still are still basin, still walls, top and bottom wall etc.

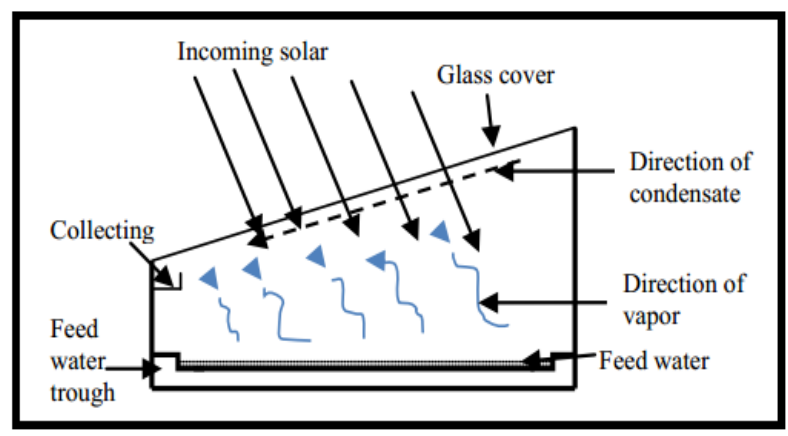

Figure 1: Operation of a conventional solar still 


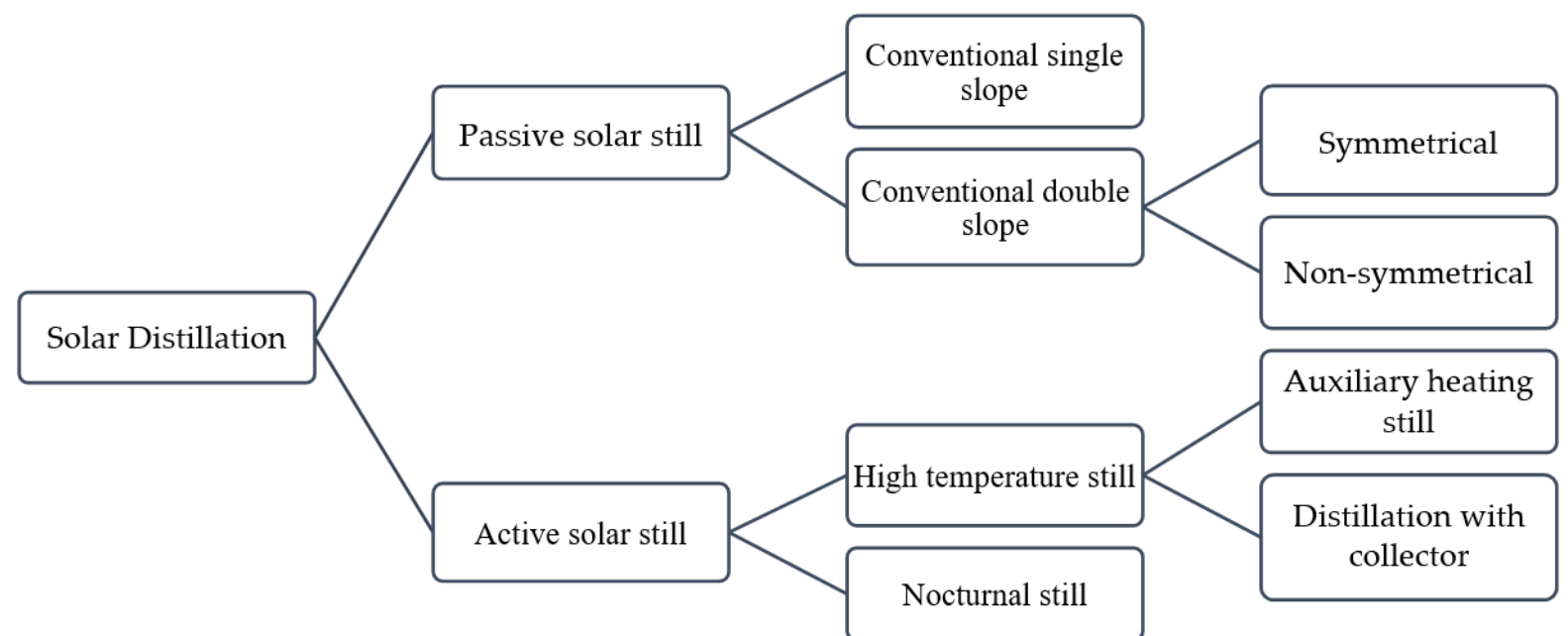

Figure 2: Flow chart of types of solar still

The solar still is designed by using CATIA and analyzed by ANSYS FLUENT. The area of the still is $1250 \mathrm{~mm} \times$ $800 \mathrm{~mm}$. The front wall height of still is $120 \mathrm{~mm}$ and back wall height is $305 \mathrm{~mm}$. The angle of tilted glass cover is $11^{0}$ that is based on the latitude and longitude of the working place. The thickness of the glass cover is $5 \mathrm{~mm}$. The three dimensional CATIA design of solar still is given in the figure 3. Also a material added in the still is indicated in the figure 4 . The reason for adding materials is to measure the inertia and also find the area, mass, volume, surface area, and center of gravity of the still before fabrication. A CATIA V5 R19 software used to design a solar still and also integrated with solar thermal system are shown in figure 6 and figure 7. After completing the design, still is analyzed by using ANSYS software. The analysis of the solar still is done by ANSYS WORKBENCH FLUENT 16. A model is meshed by using rectangular mesh tool with 10416 nodes and 8815 elements shown in the figure 5 . The named section of the model is indicated in the table 1.

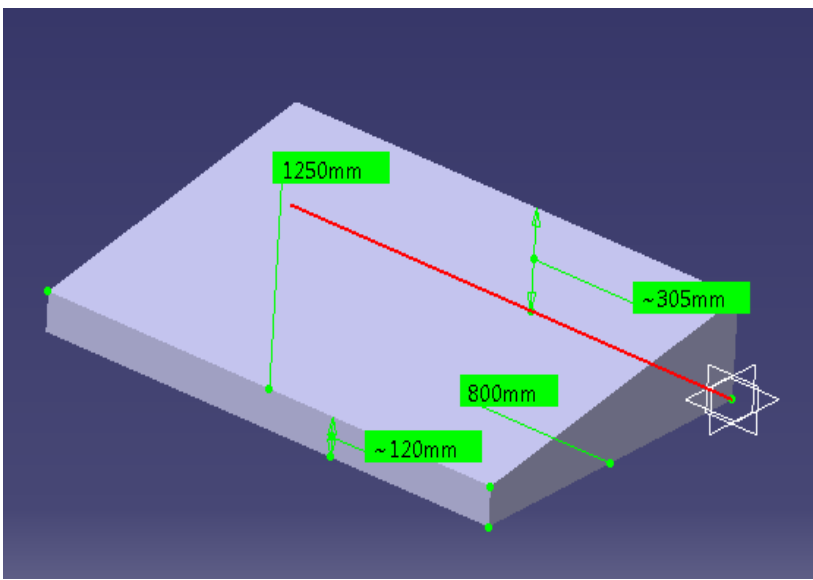

Figure 3: Three Dimensional CATIA Design

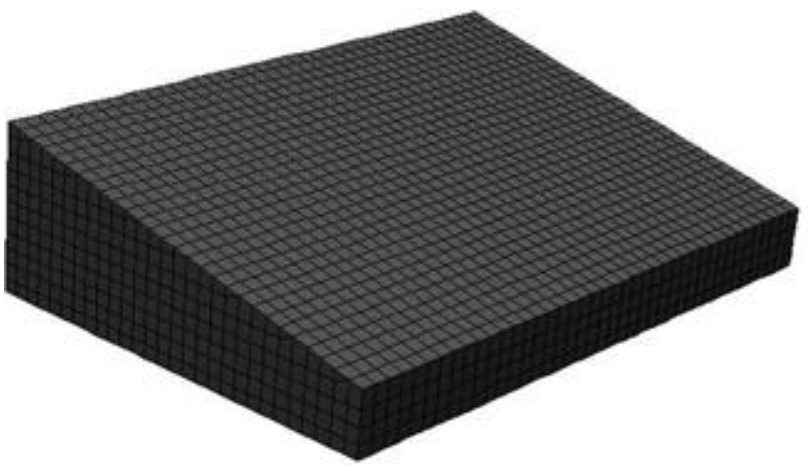

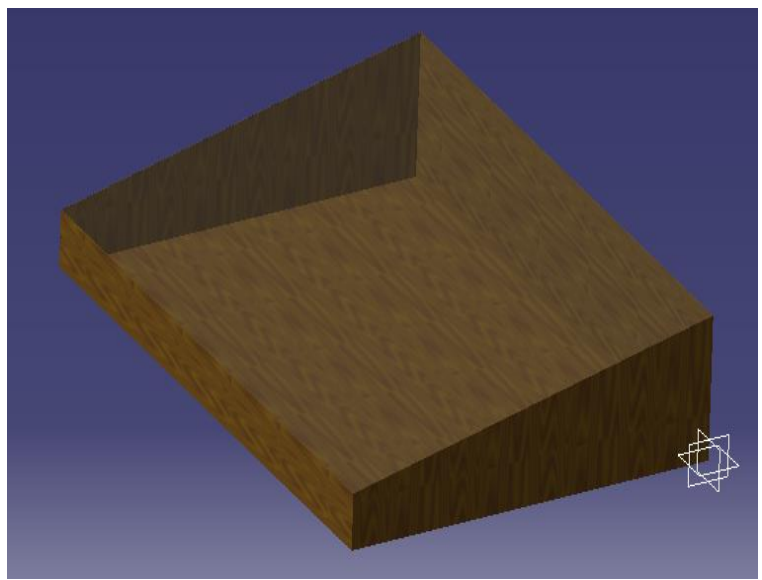

Figure 4: CATIA Design with material addition

Figure 5: Mesh distribution of the model 
Table 1: Named selection of solar still

\begin{tabular}{|c|c|}
\hline Top & Glass \\
\hline Side & Side wall \\
\hline Front & Front wall \\
\hline Back & Back wall \\
\hline Bottom & Absorber plate \\
\hline
\end{tabular}

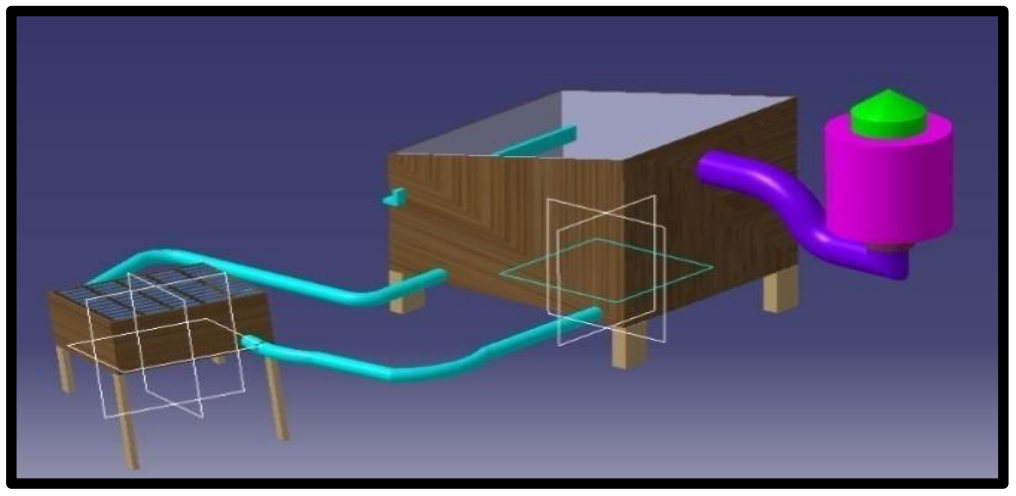

Figure 6: Still integrated with PV/T system

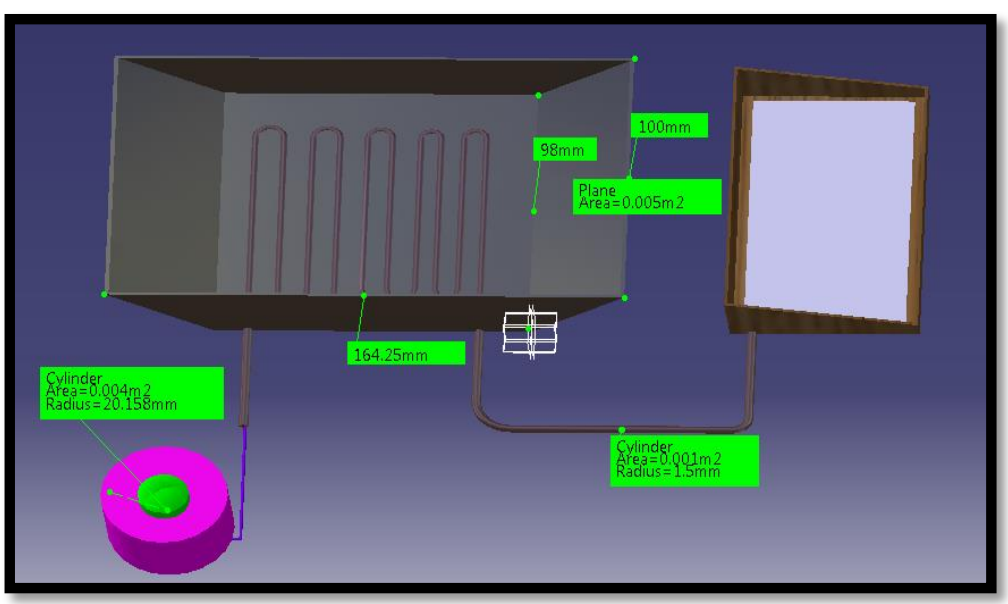

Figure 7: Still integrated with solar pond

The viscous K-epsilon 2 equation is used to analyze the still. The piecewise linear profile is created with 12 point temperature density value. The surface tension coefficient of all the phase is constant and the value is 73 . The boundary condition of the solar still in convection heat transfer coefficient is $3 \mathrm{Wm}^{2}$. The glass is selected with semitransparent property. A region is adapted with 8190 cells marked for refinement. After solution, the initiation of the graphics and animation of contour plot is obtained. The heat transfer inside the solar still is shown in figure 9 and figure 10. The absorber plate of solar still is indicated in the figure 8. Also the flow chart of mode of heat transfer is shown in figure 11.

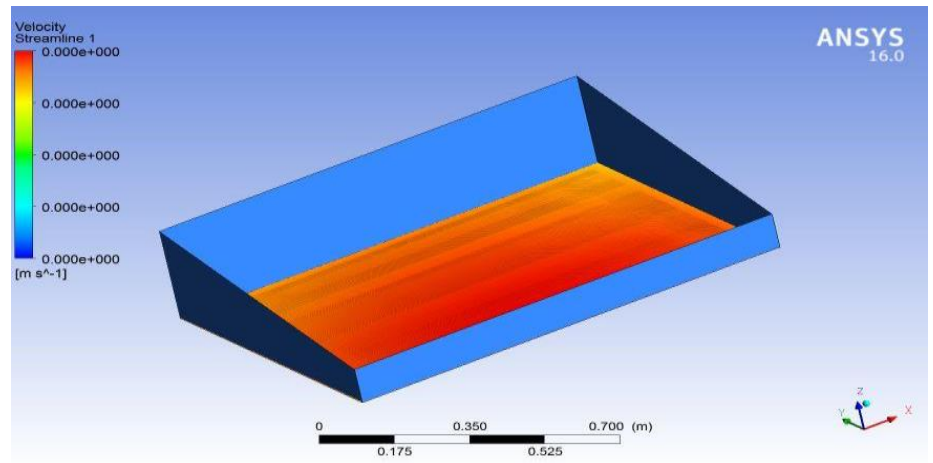

Figure 8: Sweep Surface Contour Plot 

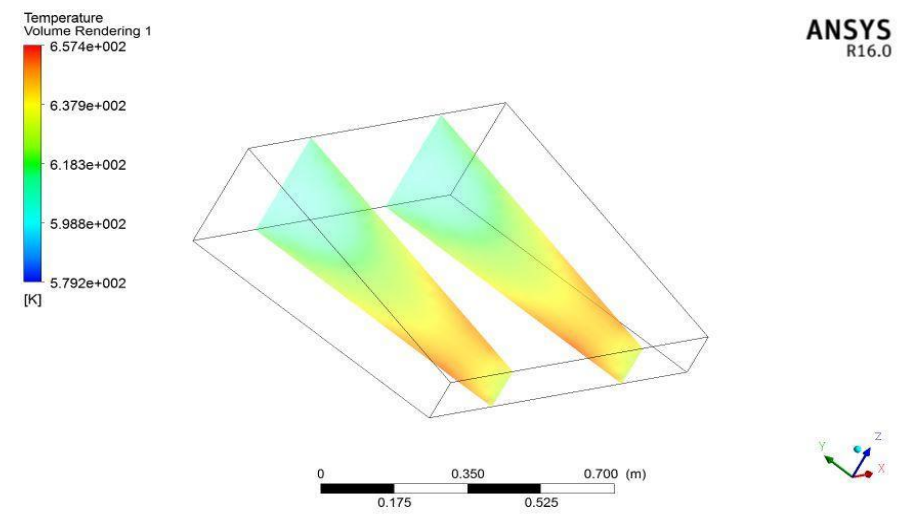

Figure 9: Temperature Volume Rendering

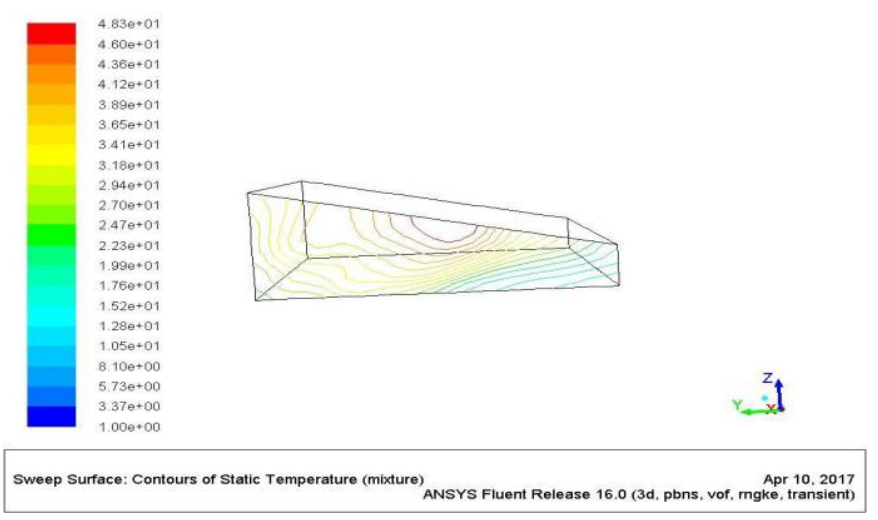

Figure 10: Contour of Static Temperature (X direction)

\section{Mathematical Modelling}

The following assumptions have been made for forming the energy balance for each of the components present in the solar still under study;

- There is no temperature stratification along the water column and glass thickness.

- The system is air tight and there is no leakage from the corners of the glass cover.

Solar flux absorbed by the glass cover is

$\alpha_{g}{ }^{\prime}=\left(1-R_{g}\right) \alpha_{g}$

Fraction of solar flux absorbed by the water mass

$$
\alpha_{w}{ }^{\prime}=\left(1-\alpha_{g}\right)\left(1-R_{g}\right)\left(1-R_{w}\right) \alpha_{w}
$$

Where $R_{g}$ is solar radiation reflected by glass and $R_{w}$ is solar radiation reflected by water

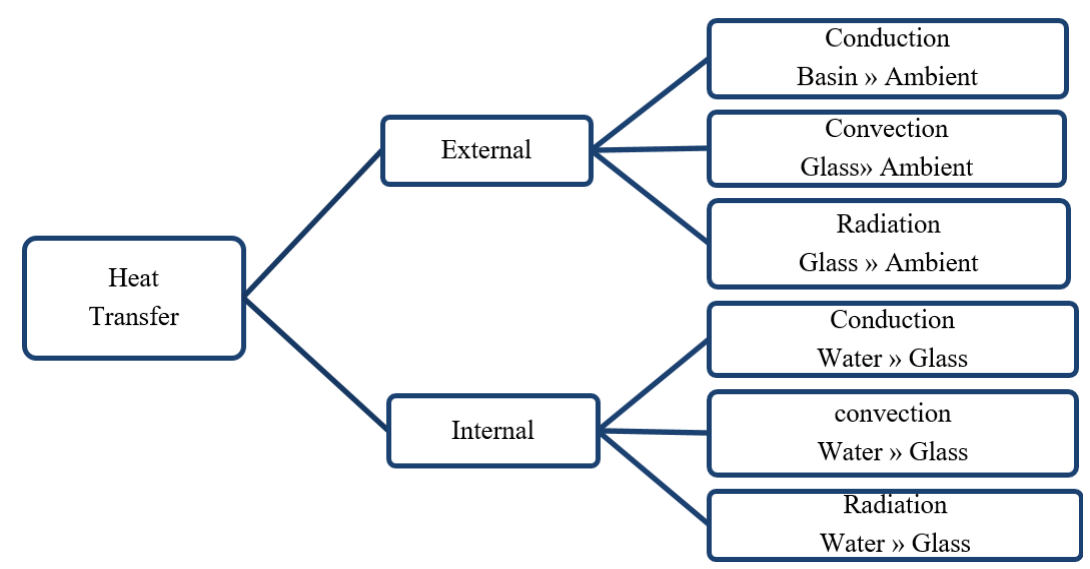

Figure 11: Flow chart of heat transfer in the still 
Fraction of solar flux absorbed by the basin liner

$$
\alpha_{b}{ }^{\prime}=\alpha_{b}\left(1-R_{g}\right)\left(1-\alpha_{g}\right)\left(1-R_{w}\right)\left(1-\alpha_{w}\right)
$$

\section{Glass Cover}

$$
\alpha_{g}^{\prime} \mathrm{I}(\mathrm{t})+\left[q_{r w}+q_{c w}+q_{e w}\right]=q_{r g}+q_{c g}
$$

Where

$\alpha_{g} \mathrm{I}(\mathrm{t}) \quad=$ Rate of energy absorbed

$\alpha_{g} \quad=$ Solar flux absorbed by the glass cover

$q_{r w}+q_{c w}+q_{e w}=$ Rate of energy received from water surface by radiation, convention and evaporation

$q_{r g}+q_{c g} \quad=$ Rate of energy lost to air

$q_{w} \quad=$ Rate of energy

Water Mass

$$
\alpha_{w}^{\prime} \mathrm{I}(\mathrm{t})+\mathrm{q}_{\mathrm{w}}=(\mathrm{MC})_{\mathrm{w}} \frac{d T w}{d t}+q_{r w}+q_{c w}+q_{e w}
$$

Where

$$
\begin{aligned}
& \mathrm{q}_{\mathrm{w}} \quad=\text { Rate of energy converted from basin liner } \\
& \alpha_{w}=\text { Solar flux absorbed by the water mass } \\
& (\mathrm{MC})_{\mathrm{w}} \frac{d T w}{d t} \quad=\text { Rate of energy stored } \\
& \mathrm{M}=\text { Mass of the water and } \mathrm{C} \text { is the specific heat capacity of water } \\
& q_{r w}+q_{c w}+q_{e w}=\text { Rate of energy transferred to glass cover } \\
& q_{r w}, q_{c w}, q_{e w} \text { are three modes of heat transfer such as radiation, convection and evaporation from the water surface to }
\end{aligned}
$$

\section{Basin Liner}

$$
\alpha_{b}^{\prime} \mathrm{I}(\mathrm{t})=q_{w}+\left[q_{b}+q_{b}\left(\frac{\mathrm{Ass}}{\mathrm{As}}\right)\right]
$$

Where

$q_{w}=$ Rate of energy transferred to water

$\alpha_{b}=$ Solar flux absorbed by the basin liner

$q_{b}+q_{b}\left(\frac{\mathrm{Ass}}{\mathrm{As}}\right)=$ Rate of energy lost by conduction through bottom/sides.

Using the above formula the mathematical calculation is done for every hour of distilled yield. Finally the yield of each hour is added to get an overall yield of the test day. The hourly distillate yield per $\mathrm{m}^{2}$ from a distiller unit can be obtained as

$$
\begin{gathered}
\mathrm{m}_{\mathrm{ew}}=\frac{q_{e w}}{L} \times 3600=\frac{6.60(35-32)}{2410654} \times 3600 \\
\mathrm{~m}_{\mathrm{ew}}=0.03 \mathrm{~kg} / \mathrm{m}^{2} / \mathrm{hr}
\end{gathered}
$$

Therefore By mathematical calculation, the total yield per $\mathrm{m}^{2}$ per day of solar still is $2.03 \mathrm{lit} / \mathrm{m}^{2} / \mathrm{day}$

\section{Fabrication details}

The experiments were conducted in three slots, one for the conventional solar still, one for the still integrated with photovoltaic thermal system and the last one is still integrated with solar pond. Also turbulence creating inside the solar still by using pump to increase the yield. The experiments were conducted from December 2016 to March 2017. In all cases the experiments were carried out from 8:00 AM to 6:00 PM. In conventional solar still for the first set of readings, yield is calculated for several days and the results were taken. The yield of the conventional solar still was calculated for the various depth of water like $4 \mathrm{~cm}, 3 \mathrm{~cm}, 2 \mathrm{~cm}$ and $1 \mathrm{~cm}$ and the results were plotted. The results show that the yield of the solar still increases with decrease in the water depth. The second set of readings were taken from the solar still integrated with photovoltaic thermal system by using a pump and make the water to flow in between the system and the results were taken. The third set of reading were taken from the solar still integrated with solar pond. Also the turbulence created inside the solar still increase the yield. For all the cases, various temperature parameters that influencing the yield of the solar were calculated using the $\mathrm{K}$ type thermocouple, 16 point temperature indicator, solar power meter and the anemometer is used for wind speed calculation, pump is used to circulate the water and relative humidity. The temperatures noted are Temperature of basin Water $\left(\mathrm{Tw}_{\mathrm{w}}\right)$, Temperature of Glazing surface inside and outside $\left(\mathrm{TG}_{\mathrm{G}}\right)$, and Temperature difference between water and glazing $(\Delta \mathrm{T})$. 
An aluminum sheet is used for fabricating the still basin with an area of $1 \mathrm{~m}^{2}$ is shown in figure 13. The bottom and sides of the basin are insulated by plywood to minimize heat losses. The glass cover of thickness $5 \mathrm{~mm}$ is used as the condensing surface and the slope of the glass cover are fixed as $13^{\circ}$ which is nearly equal to the latitude of the location (Coimbatore- latitude $11^{\circ} \mathrm{N}$, longitude $77^{\circ} 52^{\prime}$ ). The surface of the basin is painted chrome black for maximum absorption of solar radiation.

The solar still is oriented in North-South direction to receive solar radiation throughout the working hours of the day. A collector of angle $3^{\circ}$ is used to collect the water and delivery to the bottle. The droplet condensed on the glass is shown in figure 12. The continuous working of solar still, after few days the salt was deposit in the basin as shown in the figure 14. It affect the yield and it is one of the problem while testing a solar still. The deposited salt is removed by cotton cloth with free hand.

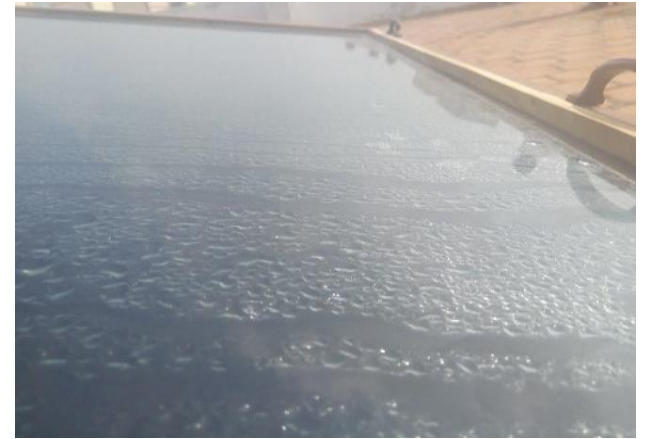

Figure 12: Droplet condensed on the glass

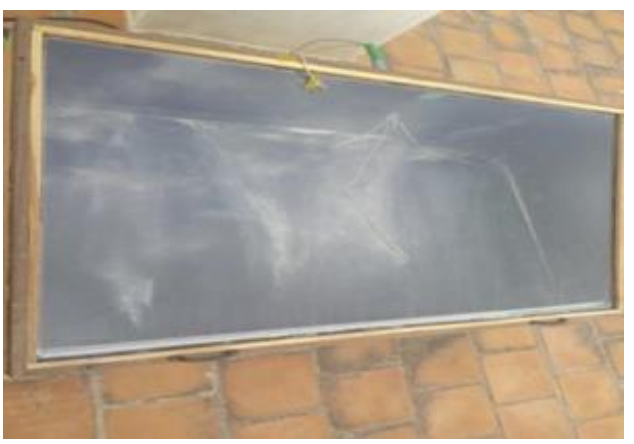

Figure 14: Salt deposition in the basin

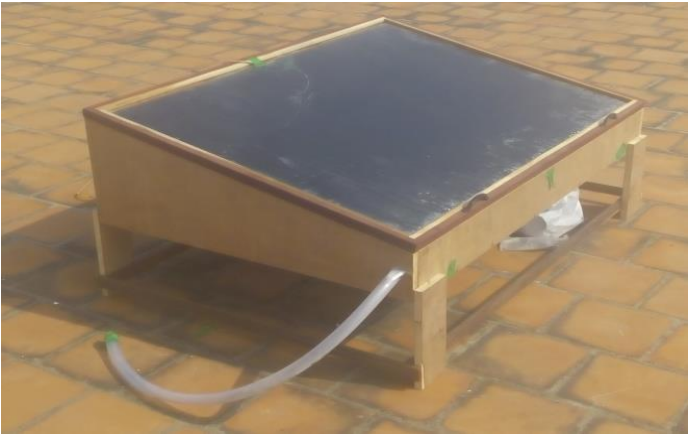

Figure 13: Experimental setup

\section{Solar Still Integrated With PV/T System}

The setup of solar PV/T collector integrated with solar still was illustrated in Fig.15. The collector have novel double glass PV panel. The size of top and bottom of the collector is $6 \mathrm{~mm}$, between these glasses silicon cells are arranged. The Aluminum absorber plate is placed below the bottom glass. The size of aluminum sheet is $0.5 \mathrm{~mm}$. Then the $10 \mathrm{~mm}$ copper tubes are placed over the aluminum absorber plate. After that the polystyrene material was placed below the tubes for insulation. The solar radiation from the Sunlight is absorbed by the PV panel. The thermal heat is transferred to the copper tubes through the frontal glass and the collector by means of conduction. Here, water has been chosen as a working fluid. The outlet hot water of PV/T panel is collected and through the still basin directly. It means a preheated water enter into the still basin increase the yield. By using the pump the continuous rotation of water from PV/T system to Solar still is done. The yield of the still integrated with $\mathrm{PV} / \mathrm{T}$ system is $3.1 \mathrm{lit} / \mathrm{m}^{2} /$ day.

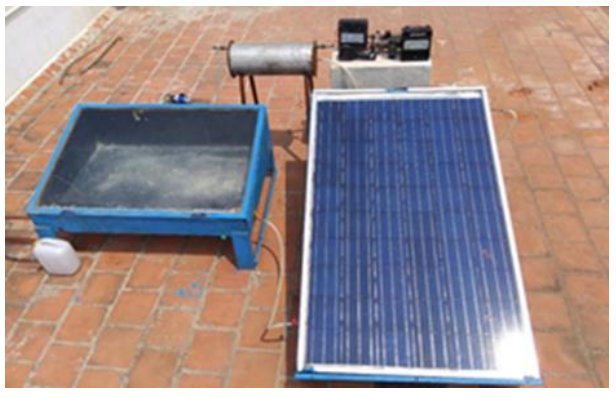

Figure 15: Still Integrate with PV/T system 


\section{Solar Still Integrated With Solar Pond}

Solar pond is constructed with trapezoid cross sections, with surface area of $1 \mathrm{~m}^{2}$ and depth of $0.5 \mathrm{~m}$. The pond was fabricated with $1.6 \mathrm{~mm}$ mild steel, iron-sheet and their bottom and sides were thermally insulated by $2 \mathrm{~mm}$ thickness of high density polyethylene. Three layer of solar pond is prepared such as upper convective zone, non-convective zone and lower convective zone. Salt solution was prepared by dissolving a calculated amount of $\mathrm{NaCl}$ and mixed with the all zone with proper proposition. Black color paint is coated inside the surface of pond which is used to absorb high solar radiation from the sun. U-bended copper tube is placed in the bottom of the pond and it is connected to the still by using the rubber tubes to extract heat from solar pond and it is given to the still. A storage tank is used to supply cold water into the pond. The setup of solar still integrated with the solar still is shown in figure 16. The yield is $2.51 \mathrm{lit} / \mathrm{m}^{2} /$ day.

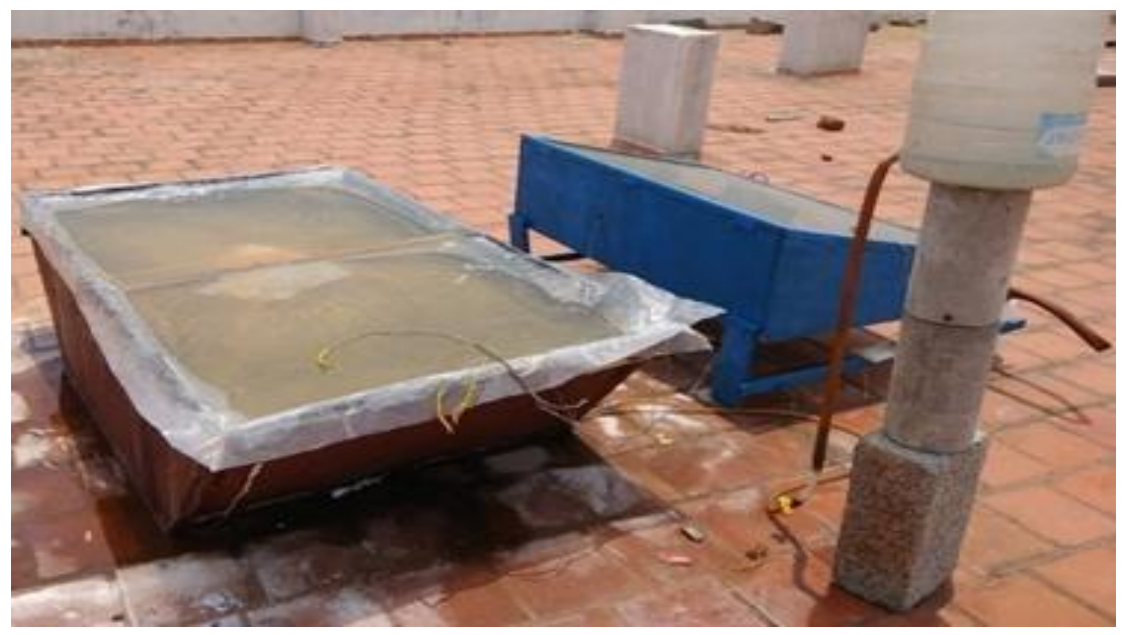

Figure 16: Solar Still Integrated with Solar Pond

\section{REsults AND Discussion}

Conventional solar still has been tested at different water depth such as $1 \mathrm{~cm}, 2 \mathrm{~cm}, 3 \mathrm{~cm}, 4 \mathrm{~cm}$. Lower water depth has high yield, when compared with the other level of water depth because of lower water level evaporate quickly as shown in figure 17. When the water depth is lower, high temperature is achieved, so water evaporate gradually and obtain high yield. Also solar still is tested when the water is supplied continuously in the form of droplet from the storage tank at optimum flow rate. The average yield of solar still is around 2 liter per day. The solar radiation, wind speed and relative humidity are also been considered during the testing process of solar still. The daily yield of the period of the project shown in the figure 18. The turbulence creating inside the solar still used to improve yield.

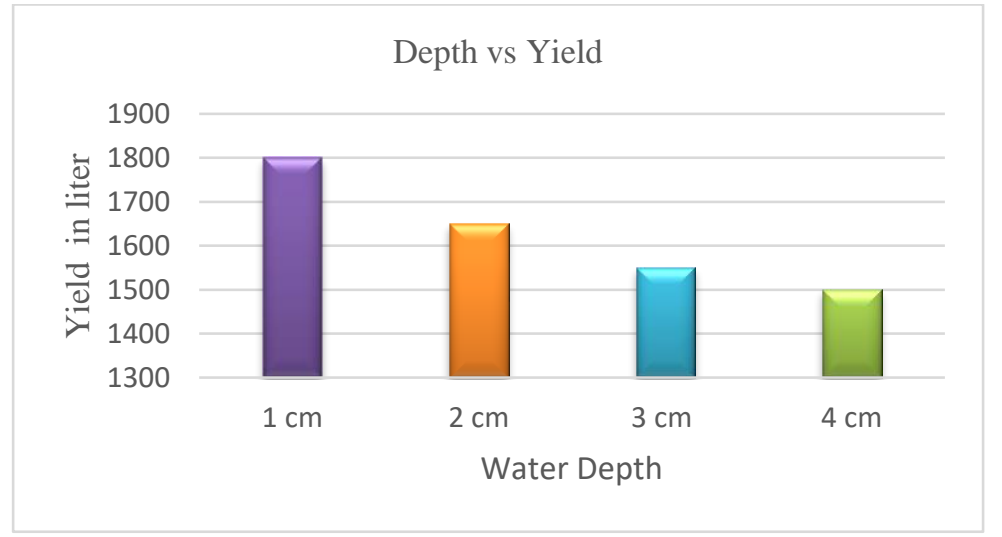

Figure 17.Comparison chart of different water depth and yield

The comparison graphs are plotted with different parameters. The solar radiation from the sun is changing from second to second and the average solar radiation is $900 \mathrm{w} / \mathrm{m}^{2}$. The difference between the basin and glass temperature is high then the yield will be high, if the difference is low then its yield will be vice versa. Therefore the difference between the glass and water temperature is directly proportional to the solar still yield. 


\section{DAILY DISTILLATE YIELD FOR THE PERIOD OF THE PROJECT}

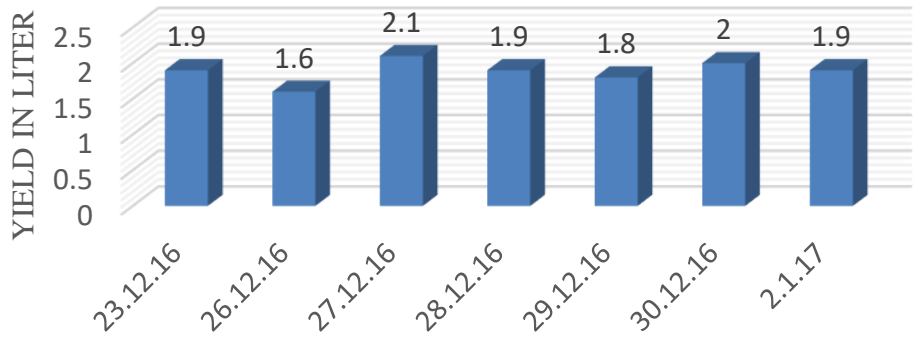

TEST DATE

Figure 18. Daily Distilled Yield

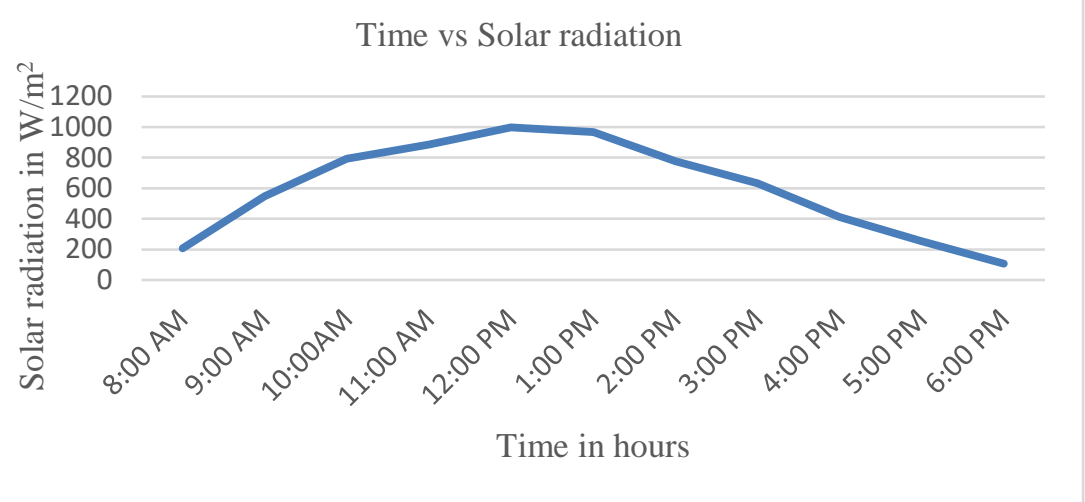

Figure 19.Comparision of Time and Solar Radiation

The comparison of the time and solar radiation of the test day is shown in figure 19. At 12:00 to 1:00 PM the solar radiation has maximum. This is the main parameter to determine the yield of the day. At evening time the different between the basin and glass temperature has maximum, so the evaporation rate increases and obtain high yield.

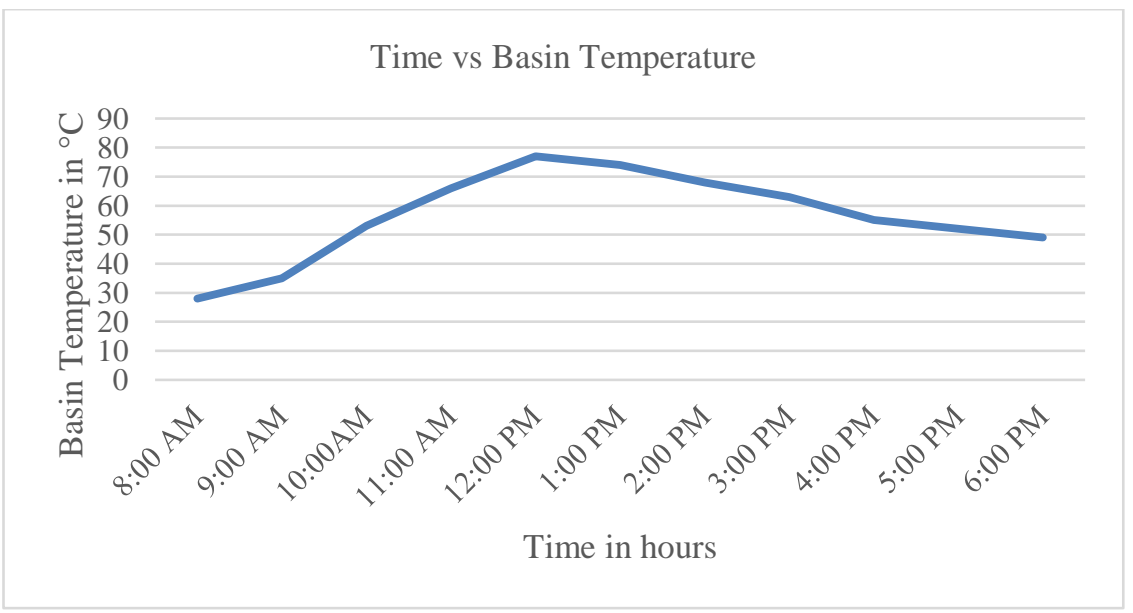

Figure 20.Comparision of time and basin temperature

The comparison of time and basin, glass temperature is shown in figure 20 and 21 . The maximum difference between the two temperatures gives higher yield after 1:00PM to 6:00PM. The basin temperature of the distiller at $1 \mathrm{~cm}$ depth which has high temperature and also obtained high yield when compared to with other water depths such as $2 \mathrm{~cm}$, $3 \mathrm{~cm}$ and $4 \mathrm{~cm}$ shown in figure 22. Increasing the yield water depth have to be low. The relation between the time and solar radiation of the solar still is shown in figure 23. The total yield of the conventional solar still (CSS) and turbulence creating inside the still and also its integration with two solar thermal systems are compared shown in the figure 24. Solar still integrate with PV/T system used to produce high yield when compare to the others system. 


\section{TIME VS TEMPERATURE}

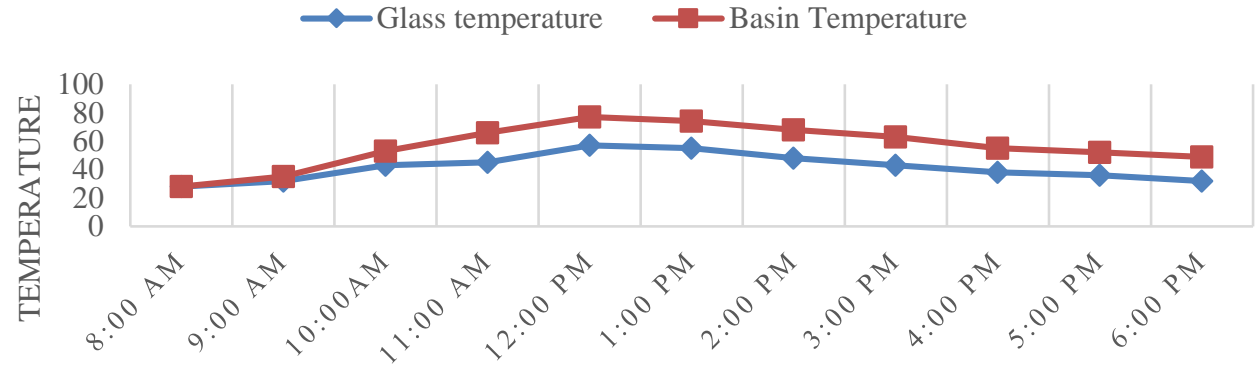

TIME

Figure 21. Difference between basin and glass temperature

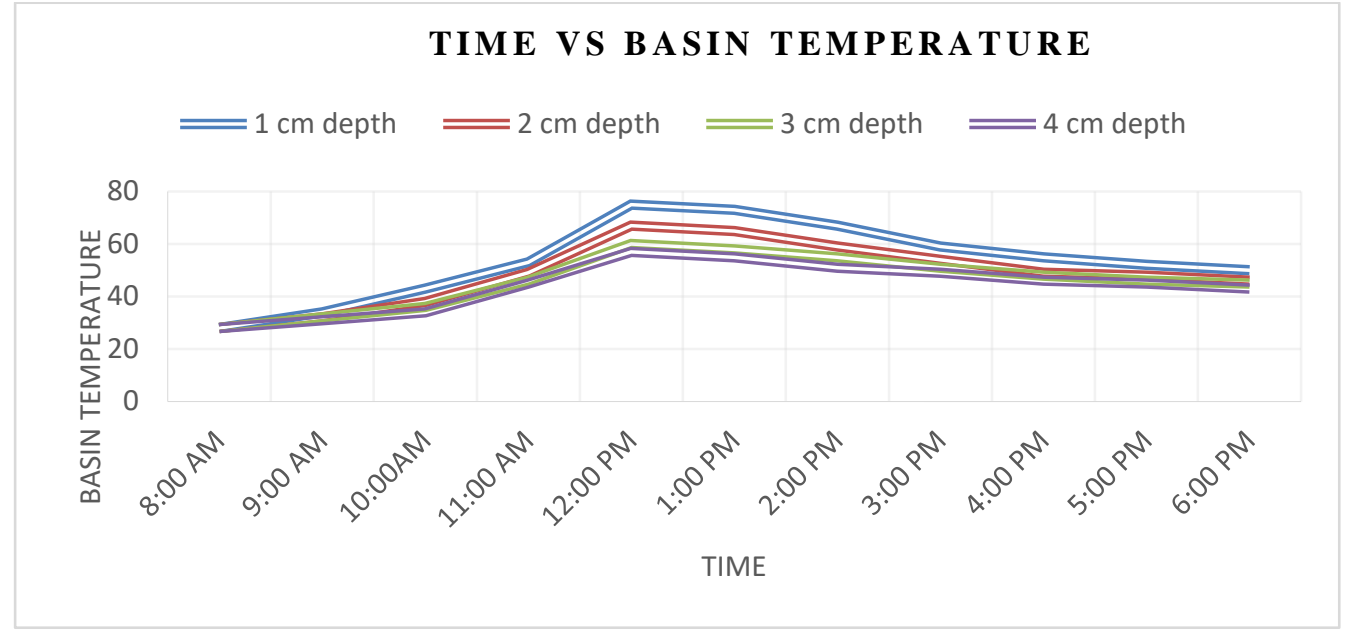

Figure 22. Comparison chart of different water depth and its basin temperature

The solar still integrate with $\mathrm{PV} / \mathrm{T}$ system has high yield because of water temperature increase in the basin. The solar radiation is observed by PV cells and the thermal heat is observed by aluminum plate attached by the PV panel and the copper tube placed below the aluminum plate has filled with water. Water collect the heat and deliver to the still basin directly. So the basin temperature increase and obtain high yield.

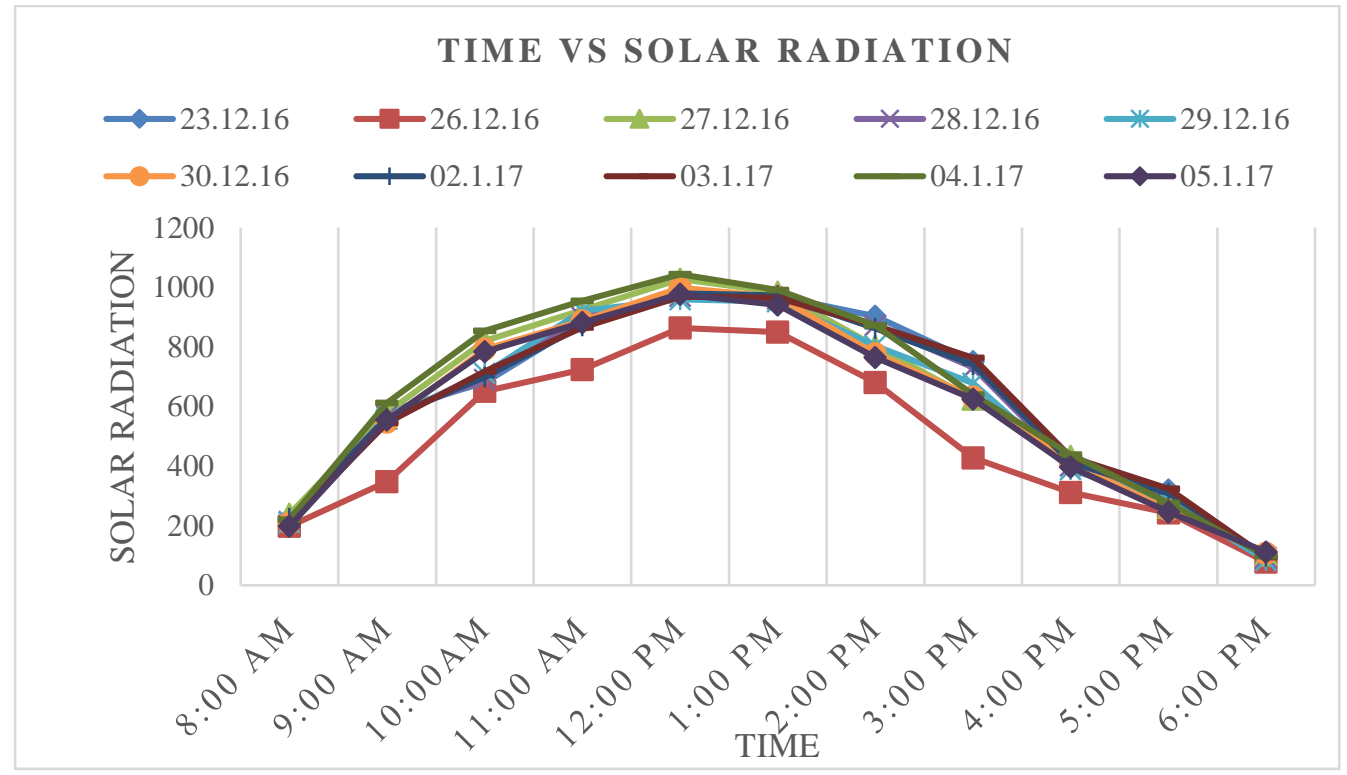

Figure 23. Comparison of Time and Solar radiation of Test day 


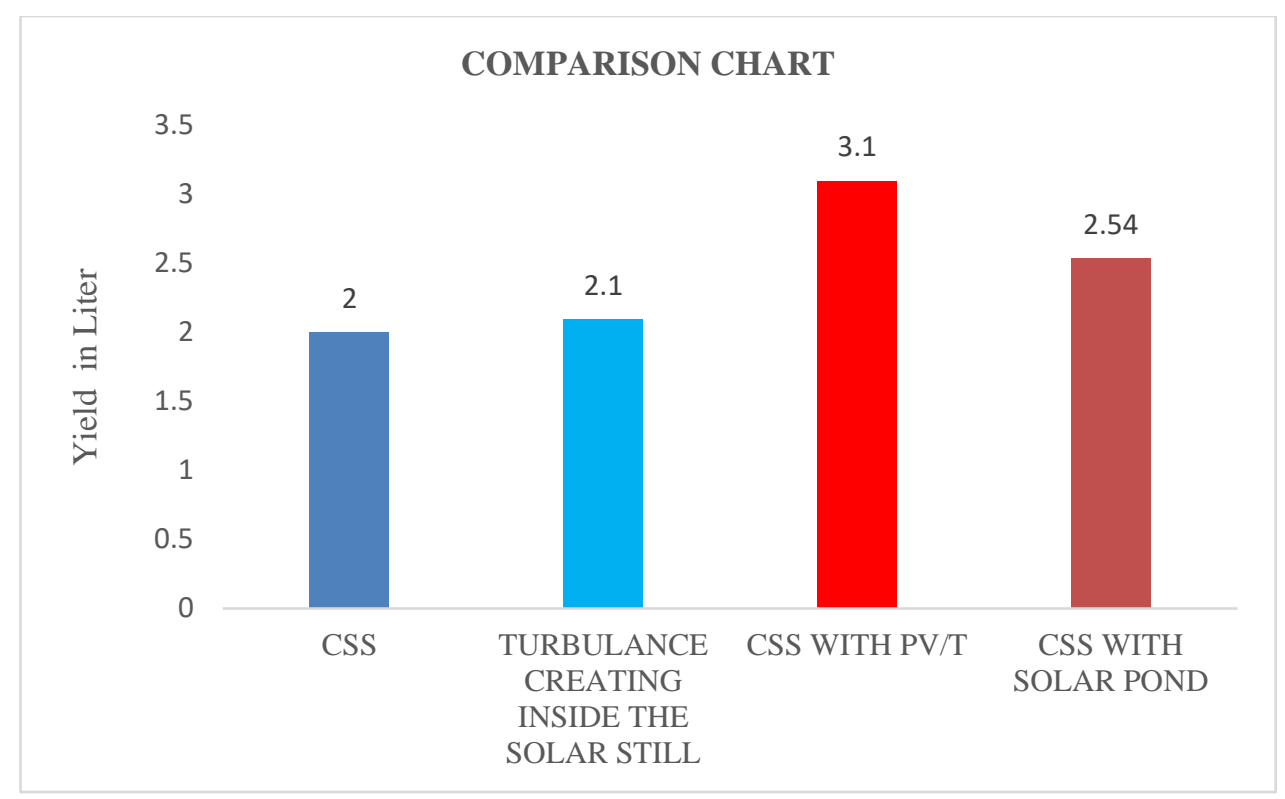

Figure 24. Comparison chart of yield of all solar stills

\section{CONCLUSION}

Solar still is an alternative simplest technology with Low energy consumption, No highly skilled labors are required for maintenance purposes. It can be used at any environment setup without causing much problem. Wind speed, Climatic condition, Solar Radiation, Water depth and Covering material maintenance are the operational parameters which will affect the solar still yield. The goal of implementing Solar still integrated with photovoltaic thermal system and solar pond to will help in hand to produce high yield.

Performance study on solar still were conducted in this project. The main purpose of executing the performance study on solar still is to analyses the various factor involved in it which enhances the efficiency of the still thereby resulting in increase of the yield and provide the route to meet the requirements. The conventional yield of solar still is $2 \mathrm{lit} / \mathrm{m}^{2} /$ day but when it is integrated with photovoltaic thermal system and solar pond the yield varies from 3.1 $\mathrm{lit} / \mathrm{m}^{2} /$ day and $2.51 \mathrm{lit} / \mathrm{m}^{2} /$ day respectively. Comparison of percentage increase in yield with all other methods of solar still are shown in Figure 25.

\section{Future Work}

- Glass is used as an outermost covering layer in almost all stills, but the maintenance of glass is troublesome. Further research has to be continued to replace the glass with some alternative materials without affecting of performance.

- Yield of the solar still can be increased by integrating with several systems such as flat plate collector, compound parabolic collector etc.

- Also yield can be increased by using absorbing materials such as sponge, fin, jute cloth and even condenser can be used to cool the still glass to increase the yield.

\section{REFERENCES}

AEl-Sebaii A. et al, describes advanced design of solar desalination systems: a review Renewable and Sustainable. Energy Review.49 (2015) 1198-1212

Al-Kharabsheh, SS., Goswami, DY., Solar Distillation and Drying (2004) University of florida 00319, USA.

Arnell NW. Climate change and global water resources: SRES emissions and socio-economic scenarios. Global Environmental Change, vol.14 (1) .p.31-52.

Bakkes JA. Background report to the OECD environmental Outlook to 2030: overviews, details, and methodology of model-based analysis. Netherlands: Netherlands Environmental Assessment Agency (MNP); 2008.

Barker R, Dawe D, Tuong T. P, Bhuiyan S. I., \& GuerraL. The outlook for water resources in the year 2020: challenges for research on water management in rice production. Southeast Asia. 1999, 1. p. 1-5.

Garg H P and J Prakash describe solar energy: Fundamentals and Applications. First revised edition.2009.

Hitesh N. Panchal describes Use of thermal energy storage materials for enhancement in distillate output of solar still: A review. Renewable and Sustainable. Energy Review.61 (2016) 86-96. 
Kabeel AE, El-Agouz SA. Review of researches and developments on solar stills. Desalination 2011; 276:1-12.

Kabeel A.E. et al, Solar still with condenser-A detailed review. Renewable and Sustainable. Energy Review.59 (2016)839-857.

Kaushal, A., Varun, 2010. Solar stills: a review. Renewable and Sustainable. Energy Review. 14, 446-453.

Kianifar, A., Zeinali Heris, S., Mahian, O., 2012. Exergy and economic analysis of a pyramid-shaped solar water purification system: active and passive cases. Energy 38, 31-36.

Muthu Manokar A. et al, Different parameters affecting the rate of evaporation and condensation on passive solar still-a review. Renewable and Sustainable. Energy Review.38 (2014) 309-322.

Sampathkumar, K., Arjunan, T.V., Pitchandi, P., Senthilkumar, P., 2010. Active solar distillation - a detailed review. Renewable and Sustainable. Energy Review. 14, 1503-1526

Sharon, H., Reddy, K.S., 2015b. A review of solar energy driven desalination technologies. Renewable and Sustainable. Energy Review. $41,1080-1118$. 